\title{
Experts applaud policy overhaul of US AIDS relief program
}

Since its inception in 2003, the United States President's Emergency Plan for AIDS Relief-PEPFAR—has spent $\$ 18.8$ billion curbing the HIV epidemic in developing countries. But after providing antiretroviral drugs to more than 2.1 million people, the massive program is now shifting its focus from treatment to prevention.

In May, as part of his federal budget request, US President Barack Obama moved PEPFAR under a new administrative umbrella-the 'Global Health Initiative' - and suggested a six-year commitment of $\$ 51$ billion for PEPFAR and malaria programs.

More recently, on 19 June, the US Senate approved the president's choice of a new PEPFAR leader: Eric Goosby, a physician and former chief executive officer of Pangaea Global AIDS Foundation.

Since his confirmation, Goosby has repeatedly stressed that big changes are in store for PEPFAR - most notably in handing over management responsibilities to local governments overseas and in scaling up prevention efforts. "Prevention is an essential component of PEPFAR and is becoming an increasingly critical priority in the absence of

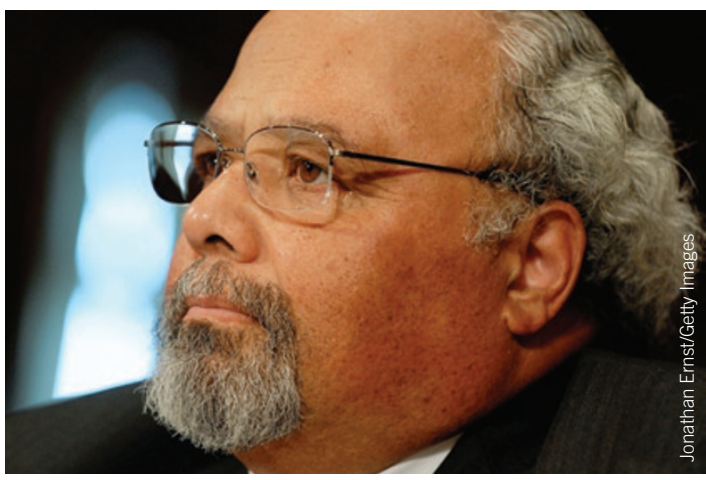

Looking to prevention: Goosby shifts focus

an HIV vaccine or cure," he told Nature Medicine in an email.

This new focus comes as welcome news to many public health experts. "[PEPFAR] badly needs some new directions," says Joanne Csete, associate professor of population and family health at Columbia University.

Under PEPFAR's original mandate, 55\% of its budget went toward doling out treatments, compared to $20 \%$ for prevention efforts.

"It really was an emergency response," notes Eran Bendavid, a global public health expert at Stanford University School of Medicine. "The biggest thrust was to place people on

\section{Rectal microbicides in development}

Despite some disappointing results from recent trials, microbicides have been touted as a potential tool to stop HIV infection through vaginal sex. Last month, however, the International AIDS Society conference in Cape Town, South Africa dedicated an entire session to rectal microbicides for the first time. "The field is picking up momentum now," says Ian McGowan, an infectious disease expert at the University of Pittsburgh School of Medicine who organized the session. "We're beginning a new phase of clinical trials."

The current focus is on testing vaginal microbicides in the rectum. Researchers have already completed a phase 1 clinical trial to test the rectal safety of UC-781, an antiretroviral being developed for vaginal use. The results have yet to be published, but McGowan, who was a co-investigator on the study, says UC-781 seemed to be safe and acceptable. Other forthcoming trials will test the rectal safety of a vaginal microbicide that contains the anti-HIV drug tenofovir.

The rectum and the vagina are "two very different environments," McGowan says, so there is no guarantee that one product will be safe and effective both places. The vaginal lining is composed of "layer upon layer of cells," he says. The lining of the rectum, in contrast, is just one cell thick, and thus more fragile. Moreover, because the rectum feeds into the colon, a larger surface area needs to be protected. Researchers are already thinking about how to design microbicides specifically for rectal use.

Money will probably be a limiting factor, however. "It's still not clear whether there's enough will from funders to do a full-scale efficacy trial for any rectal microbicide," says Robin Shattock, an immunologist at St. George's,

University of London. "That's the biggest hurdle."

Cassandra Willyard, New York antiretrovirals, which was effective at preventing death and making people live longer." In fact, African countries that received the most PEPFAR support saw $10.5 \%$ fewer AIDS deaths per year compared with their neighbors, according to a recent study that Bendavid coauthored (Ann. Intern. Med. 150, 688-695; 2009).

Unfortunately, scant data exists to estimate the rate of new HIV infections in PEPFAR-supported countries. "There's really been zero on evaluating the prevention efforts of PEPFAR," Bendavid says.

According to Bendavid, calculating these numbers would help settle the debate over PEPFAR's controversial prevention strategy: the first PEPFAR budget, influenced by George W. Bush's conservative agenda, dictated that one-third of the money for prevention efforts go toward abstinence education programs. Congress removed that earmark in July 2008, but PEPFAR still funds many faith-based organizations that push abstinence, an approach that many experts see as ineffectual.

Csete says more PEPFAR money should be spent on reaching out to groups at high risk for transmitting the virus, particularly the millions of injection drug users. Programs used by Western countries to prevent the spread of HIV through needle sharing among heroin users are illegal or socially condemned in most of sub-Saharan Africa. Methadone programs, for example, are effectively illegal in Kenya.

"With its extensive programs in a place like Kenya, PEPFAR is very well placed to raise that issue with the government," notes Csete, who detailed this argument in a June commentary (Lancet 373, 2006-2007; 2009).

Making prevention and treatment services available for these growing numbers of people will require massive new health technology infrastructures, says Catherine Schenck-Yglesias, a Monitoring, Evaluation \& Informatics Advisor at Jhpiego, a nonprofit health organization that receives PEPFAR funds.

These technologies range from computerized, long-term medical records to rigorous surveys of which populations are falling through the cracks. "Technology should be provided for host governments to manage their population health programs internally," Schenck-Yglesias notes.

Goosby, too, says that PEPFAR should encourage local stewardship of healthcare: "increasing country ownership, at the end of the day, is the only way to ensure sustainability in this fight."

Virginia Hughes, New York 